\title{
COMPARISON OF THE IDE AND HARRIS (VDRL) SLIDE FLOCCULATION TESTS IN NIGERIA*
}

\author{
BY \\ L. R. BOULGER AND D. A. CANNON \\ From the Laboratory Headquarters, Yaba, Nigeria
}

For over 10 years the Ide test has been in use in Nigeria as a simple slide flocculation test for syphilis and yaws in hospitals and clinics, and in the field, where the Kahn and Wassermann tests are impracticable. It was thought desirable that the results obtained by the Ide test should be compared with those obtained by the newly introduced Harris (VDRL) slide flocculation test, and an estimate made of the relative values of the two tests for use in the field.

The sera of 8,077 Nigerian subjects were therefore tested in parallel by the Ide, Harris, and Kahn tests. The Kahn test was used as the basis on which the comparison should be made for two reasons :

(a) It is the test which has been so far the most fully investigated as regards the comparison of clinical with serological findings.

(b) It is the standard routine test in use in this laboratory.

\section{Material}

Most of the 8,077 sera were received from the hospitals and clinics of the Lagos area. The sera of yaws cases came from a Yaws Field Survey Unit, and the sera of lepers from a Leper Settlement, both in the Eastern Region of Nigeria. The sources of the sera were as follows :

\begin{tabular}{|c|c|c|c|c|c|}
\hline \multicolumn{4}{|c|}{ Source } & & No. of Sera \\
\hline \multicolumn{4}{|c|}{$\begin{array}{r}\text { Antenatal Clinic (abnormal 451, } \\
\text { normal } 3,228 \text { ) }\end{array}$} & $\ldots$ & 3,679 \\
\hline \multicolumn{4}{|c|}{ Routine Medical Examination .. } & $\cdots$ & 420 \\
\hline Blood Donors & & .. & $\ldots$ & $\cdots$ & 108 \\
\hline V.D. and Skin & linic & $\cdots$ & $\cdots$ & $\cdots$ & 395 \\
\hline Eye Clinic & .. & $\ldots$ & .. & . & 595 \\
\hline E.N.T. Clinic & $\ldots$ & . & . & . & 220 \\
\hline Yaws Cases & . & . & . & . & 204 \\
\hline Leprosy Cases & . & . & . & . & 143 \\
\hline ner Sera. . & . & .. & . & . & .. 2,313 \\
\hline \multicolumn{2}{|c|}{ Total } & . & $\ldots$ & . & . . 8,077 \\
\hline
\end{tabular}

\section{(1) Ide Test}

When Sobei Ide and Tamao Ide (1936) introduced their colour test for syphilis in Tokyo their

\footnotetext{
* Received for publication September 23, 1954.
}

antigen was an alcoholic extract of beef heart sensitized with cholesterol and containing gum benzoin, crystal violet, and azure II. They recommended the use of whole blood diluted with 3.5 per cent. saline and low-power magnification for the reading of the result. In the Nyasaland Protectorate Annual Report for 1938, a modified Ide test was described in which it was claimed that the antigen had been made more sensitive by the replacement of beef heart by sheep heart.

Smith, Elmes, and Smith (1945), in introducing the test to Nigeria, modified it as follows :

(i) Serum was used instead of whole blood.

(ii) Inactivation of the serum was suggested but not deemed a necessity.

(iii) Readings were taken with the naked eye, with or without the use of a slit lamp.

We have used the Smith, Elmes, and Smith method with the two following modifications :

(i) The serum was always inactivated.

(ii) The 2.5 per cent. sodium chloride solution used to suspend the antigen was buffered to $p \mathrm{H} 6 \cdot 1$.

By experiment it was discovered that the results of the tests were unreliable except when the $p \mathrm{H}$ of the saline solution lay between 5.9 and 6.3 , the optimum being $p \mathrm{H} 6 \cdot 1$.

Antigen.-This is prepared as described in detail by Smith, Elmes, and Smith (1945), and must be stored in a cool, dark place. The antigen-suspension is prepared by pipetting $1.5 \mathrm{ml}$. of a 2.5 per cent. solution of sodium chloride in distilled water (buffered to $p H$ 6.1) and $0.5 \mathrm{ml}$. antigen into separate vials. The saline solution is poured on to the antigen, and, without pausing, the mixture is poured back and forth from vial to vial twelve times, without allowing the vials to drain during the process. The thumb is then placed over the mouth of the mixing vial and the vial is briskly shaken for a few seconds. This antigen-suspension is ready for immediate use, and must be used within $10 \mathrm{~min}$. The suspension is first tested against known positive and negative sera, and it is discarded unless clear results are obtained in the control tests.

Serum.-Whole clotted blood is centrifuged and the clear serum removed by a pipette. The serum is heated 
at $56^{\circ} \mathrm{C}$. for $30 \mathrm{~min}$. The test should be performed within 4 hrs of inactivation of the serum; serum to be tested more than 4 hrs after inactivation must be reheated at $56^{\circ} \mathrm{C}$. for a further $10 \mathrm{~min}$. Only clear serum should be used; a serum containing particulate matter should be re-centrifuged.

Test.-The optimal proportion of serum to antigensuspension is $1: 2$. Mixing on a 3 in. by 1 in. microscope slide is performed with either glass pipettes with rubber teats (preferably standardized by the Starrett Gauge to No. 56) or with platinum wire loops $(6 \mathrm{~mm}$.). Separate pipettes (or loops) are used for serum and suspension. The serum pipette is rinsed thoroughly in physiological saline after adding each serum. (If a loop is used, it should be flamed and cooled after each serum.) Two tests may conveniently be done on each slide.

(i) Place 1 drop (or loopful) serum on slide.

(ii) Add 2 drops (or loopfuls) antigen-suspension.

(iii) Rotate slide for $3 \mathrm{~min}$. on a flat surface, through a circle of 2 in. diameter, 120 times per min.

(iv) Read immediately, holding slide over a dark background and viewing by reflected light with the naked eye (a slit lamp is a distinct advantage).

\section{Interpretation}

Reading

No flocculation . .

Small blue floccules

Large blue floccules

\author{
Report \\ . Negative $(-)$ \\ .. Positive $(+)$ \\ .. Strongly Positive $(++)$
}

adding $0.5 \mathrm{ml}$. antigen from a 1-ml. pipette (graduated to the tip), the bottle being continuously rotated on a flat surface. The antigen is added drop by drop (taking approximately $6 \mathrm{sec}$.), the last drop of antigen being blown from the pipette so that the pipette does not touch the surface of the saline solution. The bottle is rotated for a further $10 \mathrm{sec}$. and $4.1 \mathrm{ml}$. physiological saline added. The glass stopper having been replaced, the bottle is shaken vigorously for $10 \mathrm{sec}$. The antigensuspension is then ready for immediate use and must be used within 24 hrs; it should be stored in a cool, dark place. The suspension is first tested against known positive and negative sera, and it is discarded unless clear results are obtained in the control tests.

Serum.-As for the Ide test (vide supra).

Test.-The technique is the same as that of the Ide test, except that the optimal proportion of serum to antigen-suspension is $2: 1$.

Interpretation.-The reading and reporting of the result of the test is the same as in the Ide test (except that the floccules are white).

\section{(3) Kahn Test}

The Standard (three-tube) Kahn test was employed, "Wellcome" brand Kahn antigen being used throughout.

\section{Results}

Of the total 8,077 sera, 1,134 were Kahn-positive. Of these latter, 1,107 (97.6 per cent.) gave a positive result with the Ide test, and 1,124 (99.1 per cent.) gave a positive result with the Harris rest. Of the 6,213 sera which were Kahn-negative, 6,071 (97.7 per cent.) were negative to the Ide test, and 6,040 (97.2 per cent.) to the Harris test.

Seven hundred and thirty sera gave a Kahndoubtful result; of these 505 (69.2 per cent.) gave a positive result to the Ide test, and $565(77.4$ per cent.) a positive result to the Harris test (Table I).

TABLE I

COMPARISON OF KAHN, IDE, AND HARRIS TESTS ON 8,077 SERA

\begin{tabular}{|c|c|c|c|c|c|c|c|c|}
\hline \multicolumn{3}{|c|}{ Kahn Test } & \multicolumn{3}{|c|}{ Ide Test } & \multicolumn{3}{|c|}{ Harris Test } \\
\hline Results & $\begin{array}{c}\text { Number } \\
\text { of } \\
\text { Sera }\end{array}$ & $\begin{array}{l}\text { Percentage } \\
\text { of total } \\
\text { Sera }\end{array}$ & Results & $\begin{array}{c}\text { Number } \\
\text { of } \\
\text { Sera }\end{array}$ & $\begin{array}{l}\text { Percentage in } \\
\text { relation to } \\
\text { Kahn Results }\end{array}$ & Results & $\left|\begin{array}{c}\text { Number } \\
\text { of } \\
\text { Sera }\end{array}\right|$ & $\begin{array}{l}\text { Percentage in } \\
\text { relation to } \\
\text { Kahn Results }\end{array}$ \\
\hline Positive $(++++)$ & 289 & \multirow{3}{*}{$14 \cdot 0$} & $\begin{array}{l}\text { Positive } \\
\text { Negative }\end{array}$ & $\begin{array}{r}289 \\
0\end{array}$ & \multirow{3}{*}{97.6 agree } & $\begin{array}{l}\text { Positive } \\
\text { Negative }\end{array}$ & $\begin{array}{r}289 \\
0\end{array}$ & \multirow{3}{*}{$99 \cdot 1$ agree } \\
\hline Positive $(+++)$ & 434 & & $\begin{array}{l}\text { Positive } \\
\text { Negative }\end{array}$ & $\begin{array}{r}431 \\
3\end{array}$ & & $\begin{array}{l}\text { Positive } \\
\text { Negative }\end{array}$ & $\begin{array}{r}434 \\
0\end{array}$ & \\
\hline Positive $(++)$ & 411 & & $\begin{array}{l}\text { Positive } \\
\text { Negative }\end{array}$ & $\begin{array}{r}387 \\
24\end{array}$ & & $\begin{array}{l}\text { Positive } \\
\text { Negative }\end{array}$ & $\begin{array}{r}401 \\
10\end{array}$ & \\
\hline $\begin{array}{l}\text { Doubtful } \\
(+ \text { and } \pm)\end{array}$ & 730 & $9 \cdot 0$ & $\begin{array}{l}\text { Positive } \\
\text { Negative }\end{array}$ & $\begin{array}{l}505 \\
225 \\
\end{array}$ & $69 \cdot 2$ positive & $\begin{array}{l}\text { Positive } \\
\text { Negative }\end{array}$ & $\begin{array}{l}565 \\
165\end{array}$ & 77.4 positive \\
\hline Negative $(-)$ & 6,213 & $77 \cdot 0$ & $\begin{array}{l}\text { Positive } \\
\text { Negative }\end{array}$ & $\begin{array}{r}142 \\
6,071 \\
\end{array}$ & $97 \cdot 7$ agree & $\begin{array}{l}\text { Positive } \\
\text { Negative }\end{array}$ & $\begin{array}{r}173 \\
6,040 \\
\end{array}$ & 97.2 agree \\
\hline Total ... & 8,077 & & Total & 8,077 & & Total & 8,077 & \\
\hline
\end{tabular}


In Table II the results by the Ide and Harris tests are directly compared, and the $\chi^{2}$ test is applied. It will be seen that the difference favours the Harris test, but is not highly significant.

TABLE II

COMPARISON OF IDE AND HARRIS TESTS ON 8,077 SERA

\begin{tabular}{|c|c|c|c|c|}
\hline Test & & Negative & Positive & Total \\
\hline Ide .. & $\ldots$ & 6,323 & 1,754 & 8,077 \\
\hline Harris & $\ldots$ & 6,215 & 1,862 & 8,077 \\
\hline Total & $\ldots$ & 12,538 & 3,616 & 16,154 \\
\hline
\end{tabular}

\section{Discussion}

These results show that there is very little to choose between the Ide and Harris tests, the balance being slightly in favour of the Harris test. Both tests compare very favourably with the Standard Kahn test.

In the course of the investigation, which occupied nearly a year, we decided that in both the Ide and Harris tests it was possible to make a differentiation in the positive results : many were "strongly positive"; the floccules developed rapidly and became large and very distinct. We are not aware of the significance of these results ; the clinical notes were not sufficient in number or detail to allow of a classification on clinical findings. The differentiation, however, was marked enough to warrant a scrutiny of the positive results when divided into "Positive" and "Strongly Positive".

When this differentiation is taken into consideration there is a highly significant difference between the Ide and the Harris tests in favour of the latter (Table III).

TABLE III

COMPARISON OF IDE AND HARRIS TESTS ON 8,077 SERA, DISTINGUISHING “POSITIVE" AND "STRONGLY POSITIVE"

\begin{tabular}{|c|c|c|c|c|}
\hline Test & Negative & Positive & Strongly Positive & Total \\
\hline Ide & 6,323 & 1,056 & 698 & 8,077 \\
\hline Harris & 6,215 & 928 & 934 & 8,077 \\
\hline Total & 12,538 & 1,984 & 1,632 & 16,154 \\
\hline
\end{tabular}

Although, as has been mentioned, the clinical notes attached to the specimens of serum were on the whole insufficient, and the "follow-up" of cases was largely unsuccessful, it was thought worth while to make the attempt to divide the sera examined into two groups :

(a) Sera from patients showing some evidence or suspicion of syphilis and/or yaws, present or past.

(b) Sera from patients showing no such evidence.

Vaughan (1947) states :

The evaluation of serological tests based on a comparison of results obtained by the examination of a series of unselected sera is rendered difficult by the absence of any practicable objective standards ... An attempt, however, was made to classify on clinical grounds all the sera examined as either syphilitic or non-syphilitic. The results, being thus based on data open to subjective error, have no absolute value and cannot legitimately (except as an indication of broad trends) be compared with those of other workers.

It is emphasized that our division of the sera into these two groups is based on scanty clinical notes (" data open to subjective error") and was made only in the hope of finding an indication of broad trends.

TABLE IV

COMPARISON OF IDE AND HARRIS TESTS ON 3,468 SERA FROM SUBJECTS SHOWING SOME EVIDENCE OR SUSPICION OF SYPHILIS OR YAWS

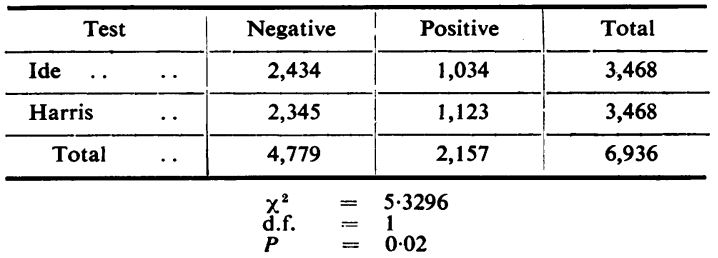

Table IV shows the comparison of results given by the Ide and Harris tests on 3,468 sera, in which the clinical notes mentioned, or suggested, a history and/or signs and symptoms of syphilis and/or yaws. The Harris test in this group was significantly more sensitive than the Ide test. When the positive results in this group were divided into "Positive" and "Strongly Positive", the greater sensitivity of the Harris test appears to be enhanced (Table V).

TABLE V

COMPARISON OF IDE AND HARRIS TESTS ON 3,468 SERA FROM SUBJECTS SHOWING SOME EVIDENCE OR SUSPICION OF SYPHILIS OR YAWS, DISTINGUISHING BETWEEN “ POSITIVE" AND “STRONGLY POSITIVE"

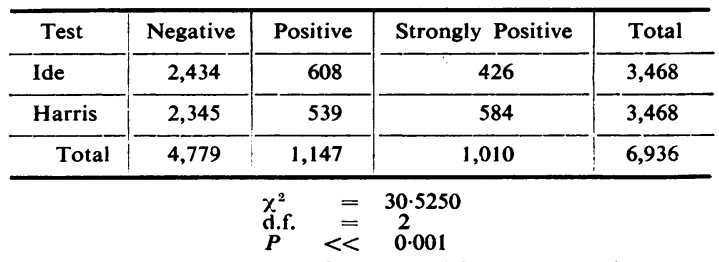

When 3,993 sera from subjects showing no evidence or suspicion of syphilis or yaws were 
examined there was no significant difference between the two tests (Table VI), but when the

TABLE VI

COMPARISON OF IDE AND HARRIS TESTS ON 3,993 SERA FROM SUBJECTS SHOWING NO EVIDENCE OR SUSPICION OF SYPHILIS OR YAWS

\begin{tabular}{|c|c|c|c|c|}
\hline Test & & Negative & Positive & Total \\
\hline Ide $\ldots$ & $\ldots$ & 3,404 & 589 & 3,993 \\
\hline Harris & $\ldots$ & 3,392 & 601 & 3,993 \\
\hline Total & $\ldots$ & 6,796 & 1,190 & 7,986 \\
\hline
\end{tabular}

positive sera in this group were divided into "Positive" and "Strongly Positive" there was a highly significant difference between the tests, the Harris test being the more specific (Table VII).

TABLE VII

COMPARISON OF IDE AND HARRIS TESTS ON 3,993 SERA FROM SUBJECTS SHOWING NO EVIDENCE OR SUSPICION OF SYPHILIS OR YAWS, DISTINGUISHING “ POSITIVE” AND "STRONGLY PCSITIVE"

\begin{tabular}{|c|c|c|c|c|}
\hline Test & Negative & Positive & Strongly Positive & Total \\
\hline Ide & 3,404 & 376 & 213 & 3,993 \\
\hline Harris & 3,392 & 327 & 274 & 3,993 \\
\hline Total & 6,796 & 703 & 487 & 7,986 \\
\hline & & $\begin{array}{l}\chi^{2}= \\
\text { d.f. }= \\
\text { o.01 }\end{array}$ & $\begin{array}{l}1.0772 \\
5.001\end{array}$ & \\
\hline
\end{tabular}

One reason for differentiating between " Positive" and "Strongly Positive" results in the Ide and Harris tests was to seek for light upon the problem of " the doubtful Kahn test "-a problem affecting both serologists and clinicians, especially the latter. Our figures, though interesting, are of no real value, again because, without adequate clinical correlation, positive Ide and Harris results by themselves (without reference to simultaneous Kahn results) are of unknown reliability.

\section{Conclusions}

The following conclusions have been reached after considerable experience of the two tests in a well-equipped and well-staffed serology laboratory ; they await confirmation after more extensive use in parallel in small field laboratories.

(1) In comparison with the Kahn test, the Harris test is slightly more specific than the Ide test.

(2) In the examination of sera from subjects showing evidence of syphilis or yaws, the Harris test is more sensitive than the Ide test.
(3) When grades of positivity are introduced, the Harris test is significantly more specific and more sensitive than the Ide test.

(4) The Harris test, when used in screening, would be more sensitive than the Ide test.

(5) There is no difference in the skill required for the performance of the two tests.

(6) The fact that the antigen-suspension in the Harris test can be used up to $24 \mathrm{hrs}$ after mixing (as compared with $10 \mathrm{~min}$. in the Ide test) is an advantage in field work.

(7) The Ide antigen is simple and inexpensive to manufacture, as compared with the complex and costly Harris antigen.

(8) There appears to be no difference in the keeping properties of the two antigens.

\section{Summary}

(1) The essential points in the techniques of the Ide test and Harris (VDRL) test are described.

(2) The results are given of the examination of 8,077 sera from Nigerian subjects by the Ide and Harris tests in parallel with the Standard Kahn test.

(3) The Ide test showed a 97 per cent. agreement with the Kahn test when testing Kahn-positive and Kahn-negative sera. Of Kahn-doubtful sera, 69 per cent. gave a positive result with the Ide test. The Harris test showed a 99 per cent. agreement with the Kahn test when testing Kahn-positive sera, and a 97 per cent. agreement when testing Kahnnegative sera. Of Kahn-doubtful sera, 77 per cent. gave a positive result with the Harris test.

(4) The results of the two tests in examining "syphilitic" and "non-syphilitic" sera, and the question of degrees of positivity in the two tests are discussed.

(5) The conclusions drawn from a comparison of the Ide and Harris tests are enumerated.

We wish to thank Dr. S. L. A. Manuwa, C.M.G., Inspector-General of Medical Services, Nigeria, for permission to publish this paper; Dr. D. W. Horn, Medical Statistician, Lagos, for much helpful criticism and assistance ; and Mr. O. U. Osoagbaka, for technical assistance.

\section{REFERENCES}

Harris, A., Rosenberg, A. A., and Riedel, L. M. (1946). J. vener. Dis. Inform., 27, 169.

Ide, S., and Ide, T. (1936). J. Lab. clin. Med., 21, 1190.

Nyasaland Protectorate (1939). "Annual Medical and Sanitary Report for 1938 ", p. 54.

Smith, E. C., Elmes, B. G. T., and Smith, J. A. (1945). Ann. trop. Med. Parasit., 39, 94.

Vaughan, A. C. T. (1947). British Journal of Venereal Diseases, 23, 77. 